ARTICLE

\title{
'We're on Flashdrive or CD-ROM': Disassembly and Deletion in the Digital Noir of Collateral
}

\author{
VINCENT M. GAINE, University of East Anglia
}

\begin{abstract}
This paper analyses the inflection of film noir that occurs in Michael Mann's Collateral, adding to a thread by Paul Schrader, John G. Cawelti and David Desser. These arguments are applied to Collateral, which features a distinctive aesthetic that I argue is 'digital noir'. Collateral both adheres to and departs from the features of noir, presenting an environment that is similar to an information system in which lives are comparable to computer programs. The film's digital cinematography blurs people and places together, reducing the very presence of the characters into digital information, captured by the camera for easier manipulation.
\end{abstract}

\section{KEY WORDS}

Digital; noir; Michael Mann; Collateral; information.

Michael Mann's 2004 film Collateral inflects the conventions and tropes of film noir in a specific way. I add this essay to a sequence of arguments made by Paul Schrader, John G. Cawelti and David Desser, as well as Jason Holt. The thread begun by Schrader and developed by Cawelti is continued by Desser and Holt, and my argument builds upon Dessers (2003, pp.536) notion of 'global noir' with what I argue is digital noir. This paper identifies the arguments regarding film noir that these critics have made, applying them to Collateral to demonstrate how it both adheres to and departs from the features of noir. Mann's film applies these features to a $21^{\text {st }}$ century American urban environment, an environment reminiscent of an information system in which people's lives are comparable to computer programs.

Collateral takes place in a single night, in which an assassin named Vincent (Tom Cruise), comes to Los Angeles to kill five key figures in a prosecution case that has been mounted against a Mexican drug cartel. Vincent coerces a taxi driver, Max (Jamie Foxx) into driving him between targets, and LAPD detective Fanning (Mark Ruffalo) pursues them after the killing of the first victim. Although the drug cartel and the FBI become involved, ultimately Max is able to defeat Vincent on his own, rescuing the final victim, Assistant District Attorney Annie Farrell (Jada Pinkett-Smith) who is herself a former passenger in Max's cab.

Over the course of its tightly focused narrative, Collateral follows many of the conventions of film noir, indeed it has been described by Steven Rybin (2007, p.171) as an example of 'neo-noir', a cycle explored in detail by Jason Holt (2006, pp.24-25). Neo-noir is also discussed by David Desser (2003, p.516), using the term 'global noir'. Desser highlights the transnational state of contemporary cinema in his analysis, considering transnational filmmaking and cross-cultural influences. In contrast to Paul Schrader (2003, p.230), who states that film noir 'is not a genre', Desser (p.516) refers to noir as a 'critical genre'. Nonetheless, both agree (as would most scholars) 
that film noir is a recognised term for a particular group of films, although the identifying features do vary.

Schrader (p.231) interprets the 'sardonic' films that proliferated in America during and after World War II as an expression of the 'disillusionment' experienced by many Americans during this period. The cycle of film noir, generally accepted as running between 1941 and 1958 (which I refer to as 'traditional noir'), draws from a number of sources, including hard-boiled literature. The detective novels written by authors such as James M. Cain, Mickey Spillane, Raymond Chandler and Dashiell Hammett express an attitude of 'awareness, loneliness and dread' (Lee Horsley 2001, p.160) towards a world where morality and goodness are dubious or even absent. Many of these novels were subsequently adapted into films of the 1940s and 50s that, among others, would later be designated as film noir.

The pessimism of film noir has been described as 'an existential attitude towards life' (Robert Porfirio 1996, p.82), the sense of alienation coupled with 'a defiant decision to embrace it and go on regardless' (Christopher Falzon 2002, p.111), or more simply, an indomitable will to define one's own being. Films such as The Maltese Falcon (John Huston, 1941), Double Indemnity (Billy Wilder, 1944), The Postman Always Rings Twice (Tay Garnett, 1946), The Big Sleep (Howard Hawks, 1946), The Killers (Robert Siodmark, 1946), Kiss Me, Deadly (Robert Aldrich, 1955) and Touch Of Evil (Orson Welles, 1958) feature protagonists who are 'thrust out in the cold, ... or 'thrown into the world' (Martin Rubin 1999, p.11), in which they must decide upon the very meaning of their lives. The heroes of film noir cannot trust objective or abstract standards of morality or justice, but must decide standards for themselves. Jason Holt (2006, pp.37-8) however observes that classic film noir still depicts justice and the rule of law:

The Production Code required classic noir to exhibit poetic justice, 'morally permissible' endings where the victims are irretrievably lost or definitively reclaimed and the guilty get what's coming to them.

Such is the case in The Maltese Falcon and The Killers, in which the femme fatale is arrested, or Double Indemnity, where the scheming protagonist is caught at the film's conclusion, or Touch of Evil, in which the corrupt police chief is killed.

The concerns of film noir continued to appear after the classic noir period of 1941-1958, as neonoir modified the traditional tropes in relation to changing social contexts. Films such as Point Blank (John Boorman, 1967), The French Connection (William Friedkin, 1971), The Long Goodbye (Robert Altman, 1973) and Chinatown (Roman Polanski, 1974) expressed the continuing issue of the 'dislocated subject' (Andrew Spicer, 2002: 145), who can only rely upon his own sense of meaning, as his surroundings are increasingly corrupted and untrustworthy. In addition, neo-noir was freed from the constraints of the Production Code, and so could depict more dubious morality and injustice. Justice might not prevail, heroes could lose, and even although the protagonist could receive vindication they were just as likely to become desolate and empty.

Chinatown is a key film in the neo-noir cycle, and it is the subject of a detailed analysis by John G. Cawelti. Cawelti (p.244) argues that Chinatown 'invokes [the hard-boiled detective story] in many different ways'. Chief among these is Chinatown's California setting and its private detective protagonist, echoing The Maltese Falcon and The Big Sleep, two of the best known films noir. The private detective is important because of his marginal (although not isolated) status, existing as an 'individual of integrity' (Cawelti, p.245) who can dispense absolute justice, whereas the criminal justice system cannot be relied upon to deliver this. The investigation of the detective frequently 
exposes that society is corrupt, rather than individuals, so his marginal status isolates him from the corruption and allows his integrity to be maintained.

In Chinatown, the marginal status of the protagonist Jake Gittes (Jack Nicholson) may prevent his corruption, but it does not allow him to ensure that justice prevails since the corruption he encounters is too vast and powerful. The overpowering influence is illustrated by the environment in which Gittes moves, the entire infrastructure of Los Angeles involved in the conspiracy which he discovers but cannot expose or defeat. Rather than the traffic of illegal goods such as drugs or Prohibition era alcohol, Chinatown revolves around the water supply of LA - the provision of a basic utility is the central stream of the conspiracy that the city is dependent upon.

Not only is corruption integral rather than marginal, but Gittes himself is 'totally inadequate to overcome the destructive realities' (Cawelti, p.249) that he encounters. Cawelti (p.250) notes that the sexual potency of the detective is negated by the 'potent perversity' of Noah Cross, played by John Huston (director of The Maltese Falcon, therefore echoing traditional noir), the film's villain who fathers a daughter with his own daughter. This figure is overwhelmingly powerful, the controller and beneficiary of the corruption in LA, and the film's horrifying conclusion implies that he will continue his incestuous "method of establishing a progeny through the agency of his daughter-granddaughter' (Cawelti, p.250). Corruption, sleaze and degradation continue to be a prominent feature of neo-noir in such films as Taxi Driver (Martin Scorsese, 1976), Body Heat (Lawrence Kasdan, 1981) and Blade Runner (Ridley Scott, 1982). Subsequent neo-noirs include Se7en (David Fincher, 1995), L.A. Confidential (Curtis Hanson, 1997), Payback (Brian Helgeland, 1999), Memento (Christopher Nolan, 2000) and Sin City (Robert Rodriguez and Frank Miller, 2005), many of which feature downbeat endings for protagonists, including those who act according to a personally defined sense of value. In Collateral Vincent operates according to 'an abstract code of conduct that allows him control over every situation in which he finds himself' (Rybin 2006, p.173), so he does not trust general standards of morality or behaviour. This selfdefined code is typical of neo-noir, supporting Collateral's inclusion in the cycle.

In a similar vein to Chinatown, Collateral features an impotent detective with the character of Fanning. Much like Gittes' discovery of his case's events but inability to stop them, Fanning surmises Vincent's plan, but at the moment of rescuing Max is killed by Vincent. The detective is not only impotent but irrelevant, the film dismissive of investigations and the knowledge they may bring. So Collateral illustrates a further transformation of the generic features identified by Cawelti, the actual removal of the detective, private or police, from the central narrative.

Alienation and marginality however remain central to Collateral. Much like a private detective, the central characters of Collateral are on the outskirts of society. As a cab driver, Max travels between places but never stays there, and Vincent is disconnected and isolated to a greater extent than a Sam Spade, Phillip Marlowe or Jake Gittes. Indeed, the title of the film indicates their adjacent status, as the word 'co-lateral' implies adjacent, alongside but disconnected. Once the detective is removed, the hero of the film is Max, who eventually defeats Vincent.

This defeat of Vincent by Max expresses 'the comforting myth of proper and improper violence' (Cawelti, p.257) that Cawelti argues is demythologised in such films as Chinatown and Bonnie and Clyde (Arthur Penn, 1967), which do not present violence as heroic or redemptive. Max does attain heroic status by saving Annie and killing Vincent, much like any number of film protagonists, including those of traditional noir such as Marlowe in The Big Sleep. Various critics describe Collateral's conclusion as disappointing, Richard T. Kelly (2004, p.50) in Sight \& Sound stating: 'The final subway chase ... feels old, right down to the endless slamming of end-carriage doors and 
Vincent's uncanny indestructibility' while Jamie Graham (2004, p.30) in Total Film writes of 'Vincent's troubling metamorphosis into besuited Terminator' and Empire's Colin Kennedy (2004, p.22) comments: 'even as we demand the only possible conclusion - a showdown - we understand that it can never really satisfy'. However, it would be overly simplistic to regard the conclusion of Collateral as a straightforward affirmation of good over evil, as there are a number of factors which problematise such a reading.

Much as Bonnie and Clyde complicated the 'mythical simplification' (Cawelti, p.258) of good and evil opposition, so Collateral presents an ambivalent view of heroism and compassion. In contrast to the corruption and evil of Chinatown and traditional noir, the environment of Collateral is indifferent. The indifference of the film can be found in the plot, characters and the diegesis as a whole.

As noted above, the film's title refers to adjacent people who become involved in the events of the narrative. In his DVD commentary, Mann describes this narrative as 'the third act in a traditional drama' - the events of the story are adjacent to a much wider story involving a federal case against the drug baron Felix (Javier Bardem). This wider story could be part of a different film (or TV series, such as Traffick or The Wire) that instigates the plot of Collateral, but only makes a brief 'appearance' in it. The FBI, headed by agent Frank Pendrosa (Bruce McGill) is concerned with their case against Felix, who wants the case against him stopped. These characters appear briefly in the film, after Max throws away Vincent's preparatory work on his targets. Vincent coerces Max to obtain another copy of the list from Felix at the drug baron's nightclub, which the FBI have under surveillance. When Max visits the club, the plot of Collateral intersects with the larger story that does not otherwise appear in the film. Therefore, the larger story is indifferent to the relatively minor plot of Vincent and Max - the events of Collateral would be unnoticed were it not for a random act by Max (to which I return later).

The attitudes of both the FBI and Felix demonstrate the indifference which is facilitated by digital technology. The FBI has four witnesses and a DA ready to try the case, but the agents are unprepared for the series of hits on these key figures. When they learn of the assassinations, their response is gleaned entirely from their surveillance equipment - digital cameras capture Max entering Felix's club and giving his name as Vincent. Based solely upon this, they determine that Max is actually Vincent and therefore is to be stopped. Fanning attempts to persuade them differently, believing that Max is being coerced. The FBI are dismissive of Fanning's opinion, indicating indifference towards alternatives - all that matters is their case and their specific handling of it. Crucially, their assessment and plan of action is derived entirely from their digital surveillance - Fanning's more 'human' investigation that involved inspecting bodies and talking to witnesses is disregarded. Human interaction is removed from decisions, as digital information determines action.

Felix is similarly indifferent, partly due to digitisation. He is not associated with the people whose deaths he facilitates, his only concern is that they be removed. He refers to them as 'fingers' and 'informants', with no acknowledgement of them as people. This is not surprising for major figures in crime films, senior gangsters from The Godfather (Francis Ford Coppola, 1972) to Gomorrah (Matteo Garrone, 2008) treat the lives of others as expendable, but Felix's attitude is peculiarly indifference. During his scene with Max (who is posing as Vincent), Felix remains calm and dispassionate, until he learns that the list of informants has been lost. Felix's ire is prompted by the waste of resources, since compiling the lists of informants required what he describes as 'signal interceptions with voice recognition software, surveillance; a very expensive counter-intelligence' operation. This abstract economic view indicates Felix's indifference to the physical world, as he 
betrays no fear or even concern over the possibility of him being indicted after all.

Felix's emphasis on the technology used to gather the list demonstrates the digitisation of human identity, and the disassociation that digitisation allows. The technology distances him from the informants, reducing them simply to information which he then places on a memory stick. With this information, Vincent is able to resume his task. He has been doing this since the beginning of the film, but this sequence with Felix illustrates how digitisation allows indifference. Once reduced to digital information, people are only information, their identities converted into files that are easily deleted.

The indifference facilitated by digitisation is further illustrated by the film's style, as Collateral inflects the stylistic features of traditional noir. Schrader outlines seven key features, most of which can be found in Collateral. In film noir, 'the majority of scenes are lit for night' (Schrader, p.235) and Collateral takes place entirely in one night. Film noir favours 'oblique and vertical lines' (p.235) over horizontal, creating a distorted and splintered image. Collateral does not have an excess of oblique lines in its mise-en-scène, although they are apparent in an earlier Mann film, Manhunter (1986), which has also been described as a neo-noir (Holt, p.29-31). Vertical lines however are in abundance in Collateral. The tall skyscrapers of Los Angeles surround the characters, and when Max runs over a bridge crossing a highway the vertical bars of a safety barrier enclose him. The taxi cab itself provides vertical lines, as a transparent partition forms a separation between Max and Vincent throughout. The skyscrapers and freeways, night clubs and apartments of Collateral are a $21^{\text {st }}$ century update of the sleazy bars, alleyways and docks frequented in traditional noir, and the abundance of vertical lines form barriers and obstacles that the characters must move around and between. The resultant environment is one that is circumscribed and fixed, the movements of people restricted between these structures.

The architecture of the film aids the build-up of tension as opposed to 'physical action' (Schrader, p.235) which is also key to film noir. While Collateral does have explosive action sequences, these are tightly contained by their locations, particularly in the film's major set piece, a gunfight in a nightclub. The scene is largely shot at the level of the dancers, the camera hemmed in and squeezed between the clubbers. Within 'this closed-in techno environment' (Rybin, p.180), the actions of Vincent, Max, Fanning and the FBI, as well as Korean and Mexican gangsters, are contained and restricted, the physical space restricting and disorientating.

Missing from Collateral are 'romantic narration' and a 'complex chronological order' (Schrader, p.236) many films noirs using flashback and voiceover. Collateral tells its story straightforwardly, but as noted above, the plot is part of a much larger story involving a federal investigation. Vincent admits twice that he does not know who his victims are, although he recognises what he describes as the 'witness for the prosecution look about them'. The digitisation performed by Felix's counter-intelligence operation has reduced these people to no more than targets for Vincent to eliminate. The film's narrative for the most part supports this view, by not including additional details about the victims (in most cases). Vincent's indifference is an appropriate regard for these targets, and the city as a whole displays a similar regard.

Rather than portraying the 'sordidness of the urban crime film' (Schrader, p.232), the Los Angeles of Collateral is sleek and streamlined, but this is integral to the digital noir as well. Water, another stylistic feature of film noir (Schrader, p.232), may not be apparent, but other reflective surfaces abound: the steel and glass buildings, the smooth bonnet of Max's cab, even the eyes of coyotes 
that cross in front of the car. The sleek reflectiveness of the city and its architecture aids the characters' journey and the film's narrative - through this environment progression is easy, the murderous mission of Vincent is not interrupted because the city is too smooth. This smoothness allows the city's continuation, and its indifference. By not featuring obstructions to the events that unfold, the city is not concerned or disrupted by these events.

The lack of disruption, or even acknowledgement of the deaths (except by Max), is the indifference of the film's overall environment. Vincent's lack of concern makes him the personification of the city's indifference, as he moves easily between one target and another. The smooth cinematography of the taxi's motion underscores the hitman's ease of motion, and the actual filming itself has a significant effect.

This city is not seen by the light of day, but nor is it simply steeped in darkness. Shadow, the final feature identified by Schrader (p.235), abounds in film noir, giving the environment 'an equal or greater weight than the actor'. With black and white cinematography, a black shadow might cover the character's face, but Collateral's visual style has a different effect. Much of the film was shot on High Definition Digital Video, Mann and his cinematographer Dione Beebe using the Thomson Grass Valley Viper FilmStream and the Sony CineAlta (Rybin, p.170). The effect of this technology is to capture a far wider range of colours and tones than $35 \mathrm{~mm}$ film can record. Digital filming merges the characters with their environment, the colours of their skin, hair and clothing blurring into the multi-hued palette that is the Los Angeles of the film. This blurring gives equal emphasis to the people and the environment, in a manner similar yet distinct from traditional film noir.

Vincent himself is the most obvious example of the digital blurring. His suit and tie are grey, as are his hair and the stubble that covers his jaws and throat. Various critics have commented upon this, Mark Olsen (2004) in Sight \& Sound drawing attention to Cruise being 'dressed in a designer suit, with steel-grey hair and neatly clipped stubble'. Manhola Dargis (2004) in her review for The New York Times comments that Vincent is 'Nattily turned out in a gray suit and matching salt-andpepper hair and light beard' and David Gritten (2004) in The Daily Telegraph remarks that 'Cruise appears as never before: with grey, swept-back hair, a salt-and-pepper beard and a cold-eyed stare'. Vincent's appearance is a distinctive inflection on Cruise's star persona, but it is a typical part of Collateral. Vincent's greyness indicates his lack of distinctive identity - his nondescript appearance allows him to move unnoticed through LAX, a hospital, a nightclub and the building that houses the US Attorney offices.

The other characters in the film are also dressed in dull shades: Max wears cream trousers, a dark grey hoodie and a green t-shirt, while Annie is in a dark pinstripe suit. Detective Fanning wears a dark coat over a beige suit and black shirt. Within the palette of the mise-en-scene, these figures do not stand out. The digital cinematography merges them with the indifferent environment. Vincent's appearance is merely the final stage of the disassembly, as digital noir takes everyone to pieces.

A key example of this effect occurs in Annie's office building. Vincent has cut the power so the scene is drenched in shadow. In a close-up, Vincent's head rises into view to the right of the frame, while the rest of the shot is occupied by the expanse of downtown LA, viewed through the office 
window. The colouring of Vincent's face and hair is similar to the buildings outside. These greys blend into the brown of the highway, which combine with the myriad of lights from cars and other buildings to form a collage of colours, none more distinctive than the rest. This is the de-emphasis caused by digital filming - human colouring becomes part of the environment without standing out.

This particular scene also demonstrates the indifference of the digital noir environment: life-anddeath events are occurring inside the building, but the city continues without disruption. Were the image simply pitch black, with nothing but darkness outside the window, isolation and emptiness would be suggested. With the multi-hued palette made possible by digital filming, Collateral depicts the environment that has no regard for what happens to those within it. It is not an oppressive blackness, but a multi-coloured yet disinterested world in which these events takes place. Vincent is about to execute Annie when Max intervenes. Vincent asks Max 'what're you gonna do?' expecting nothing. Indeed, why would he expect anything? Nothing in this world cares anyway.

The digital filming not only blurs people and places together, but reduces the very presence of the characters into digital information, captured by the camera for easier manipulation. The act of filming serves to disassemble people and places into binary sequences, just as characters are within the narrative. Therefore, digital noir can be defined as the reduction of people and environments into digital information, both by style and narrative, within a context featuring the elements of film noir.

Vincent's disassembly is further indicated by only fragmentary information being given about him. The film's tight focus omits such details as where he comes from, what training he has had and why he is an assassin. This omission is not uncommon within the sub-genre of the assassin thriller, to which Collateral also belongs. The titular assassins of The Day of the Jackal (Fred Zinnemann, 1973) and The Jackal (Michael Caton-Jones, 1997) are anonymous, known only by a code name. The killer of In The Line of Fire (Wolfgang Petersen, 1993) is a product of US Intelligence who does not remember who he was beforehand. In The Terminator (James Cameron, 1984), the assassin is literally inhuman, being an implacable machine, and reviewers have made the comparison between that cyborg and the hitman of Collateral (Graham, p.30). In The Bourne Ultimatum (Paul Greengrass, 2007), one assassin has lost his memory, while another is referred to by his handlers as 'the asset'. The implication is that an assassin is not a person, but a device designed for a specific purpose. Within the digital noir an appropriate term for Vincent would be a deletion program, designed to enter a system and erase files.

As discussed earlier, humanity's digitisation is demonstrated in the film, as Vincent is provided with a computer and memory stick giving the details of his targets. People have been reduced to digital sequences by the act of filming itself, while within the narrative they are similarly reduced through surveillance and voice recognition software. When people become no more than information, the act of killing is comparable to the tapping of a keyboard. Vincent describes people as: 'a speck ... gone in a blink. That's us, lost in space'. Equally, a file is deleted in a blink, and people cease to exist. The simplicity with which Vincent views his operation is made possible by digitisation - people are reduced to information and information is erased. There is no concern over the deletion of a file, so Vincent's indifference towards their deaths is appropriate. It is generically typical for an assassin not to care about his targets, but Vincent's attitude is one 
supported by the film as a whole. Since people are no more than information, why should they be regarded as any more significant than a file? Vincent's attitude is shocking to Max, but it is entirely appropriate within the digital noir environment of the film, where people do not stand out in the image, but are disassembled into digital information along with the landscape.

By virtue of his indifference, Vincent is a specific inflection of the noir anti-hero. Schrader (p.2378) discusses three phases of noir and the protagonists found within them. The first is 'the phase of the private eye and the lone wolf' (p.237), predominantly detective stories. The second 'tended more toward the problem of crime in the streets, political corruption, and police routine' (p.238), and a concern with realism. The third is 'the period of psychotic action and suicidal impulse' (p.238), in which 'The psychotic killer ... became the active protagonist' (p.238). Schrader describes this third phase as the logical conclusion to 'ten years of despair' (p.238), as protagonists became mentally unstable and psychotically violent. Such 'end-of-the-line noir heroes' (p.239) reached their peak with Mike Hammer (Ralph Meeker) in Kiss Me, Deadly. Hammer is mean, brutish and ineffectual, and his investigation ultimately uncovers an exploding atomic bomb. Hammer, and the noir protagonist overall, becomes irrelevant 'in a world where the [A-]Bomb has the final say' (Schrader, p.239). The world of Collateral is a continuation of the environment of Kiss Me, Deadly. Vincent is not psychotic, and commits acts of violence because that is his job, rather than out of anger or frustration. He is able to be detached and indifferent because he is simply erasing computer files. The city has the final say: no one will notice the deaths that have occurred and the city will continue without disruption.

Max is a different kind of protagonist, with ostensibly heroic qualities. Cawelti identifies in Chinatown and similar works of the 1970s 'the use of traditional generic structures as a means of demythologisation' (p.254), as the hard-boiled detective is reduced to an ineffectual figure in the face of a corrupt world. But in the indifferent world of Collateral, where the assassin represents the status quo and the detective is disposable, it is the cab driver who makes a startling choice. After realising the full extent of Vincent's inhumanity, Max reacts with a series of random acts.

That Max becomes involved in Vincent's operation at all is coincidental, and David Desser (2003, p.531) notes that transnational 'global noir insists on the unrelated nature of [its] characters'. Prior to the night of the film's events, Annie, Max, Vincent and Fanning have never met, nor would have cause to, but as Vincent observes there are 'fates intertwined'. Desser draws attention to chance encounters in cars, and Max's taxi cab is the vehicle (literally and metaphorically) that brings these characters together. Both Annie and Vincent are passengers for Max, but Max learns that Annie is Vincent's final target after he has crashed the car and Vincent has escaped. Max is outside the car, but sees Annie's picture on the screen of Vincent's computer inside the cab. Even after the cab has been wrecked, it remains the site of chance meetings.

Desser (p.532) argues that the automobile 'best represents the postindustrial landscapes of global noir, the atomisation of the individual'. This landscape is that of the digital noir, the highways of LA, captured in various aerial shots, similar to the networks of a computer system. Within this network, the car is a digital unit that carries a single person between locations. In the aerial shots, the blips of light from car headlights suggest information running from one data processor to another. Although the roads link areas together, the different files/people operate independently of each other, such as Annie and Fanning. Both have their function within the criminal justice (computer) system, but have no interaction with each other. Such disconnectedness and lack of interaction facilitates the deletion of individual files - any can be erased without the overall urban system being disrupted. The system's continuance is illustrated by the ongoing progress of Max's 
cab: the cinematography that captures the car's journey is smooth and fluid, often depicting the car running along a straight road without needing to turn. Despite the deaths that occur, and even the gun battle in Club Fever, the network is not disrupted, vehicles continue to flow like data, and Vincent continues to delete files according to his own programming.

Within this network, Max makes some random acts which at least interrupt the Vincent program. Initially, Max is the victim of coincidence, picking up a hitman and then having the first body land on his roof. Many of the films discussed by Desser (p.532), such as Amores Perros (Alejandro González Iñárritu, 2000), Esprit d'amour (William Chang, 2000) and Shark Skin Man and Peach Hip Girl (Katsuhito Ishii, 1998), feature car accidents. By contrast, Max defies Vincent's instructions by deliberately crashing the car (although this act is a reaction, as discussed below). In doing so, he escapes from the containment of digitisation, breaking free from the unit of his digital imprisonment. This interrupts Vincent's smooth operation, the deletion program prevented from the completion of its processing.

Max's defiance of Vincent leads to the most obvious departure from the doom-laden narratives of both traditional and global noir: at the conclusion of Collateral Max is able to defeat Vincent and save Annie - his personal choices actually make a difference, unlike Gittes in Chinatown who is unable to save the woman he loves nor stop the man he opposes. But although Max's triumph could be viewed as 'the affirmation of myth as myth' (Cawelti, p.259), it is a series of random acts that allow Max to triumph over Vincent. These events are an aberration in the smooth running of the digital noir system, and require close attention.

Max's acts are reactions, which creates a sharp contrast to Vincent's single-minded programming. An early indication of the cab driver's randomness is when he steals Vincent's briefcase which contains the hitman's preparatory work. His motivation for stealing the case is simply that Max's mother Ida (Irma P. Hall) and Vincent are humiliating Max through their conversation. When Vincent has Max cornered, in desperation Max throws the briefcase off a bridge, an act that necessitates the visit to Felix. Later, in defiance of Vincent's control over him, Max crashes the cab. He notices, by chance, Annie's picture on the computer screen and reacts by running to her rescue. When Vincent has Annie cornered, Max shoots the hitman unexpectedly. The blackout on the train occurs randomly, and in desperation, Max shoots at Vincent. By pure luck he hits the assassin in the chest. Whereas Vincent operates with programmed precision, Max is random and unpredictable. Max's decisions are not pre-planned, simply reactions to circumstances. Therefore, he is not acting in defiance of the overall system, simply responding to particular events within it.

In the information system city of digital noir, Max's actions are random sequences of code, causing glitches in the system that destroy the Vincent program. These glitches however do not alter the system, which continues without interruption. In the final shots of the film, Max and Annie stagger off the train and head back towards the highway. They appear to be looking for a taxi or a lift, which will be their re-entry into the flow of information in the LA network. The vertical lines of pillars, buildings, telegraph poles and pylons surround them, maintaining the enclosure of the digital noir city. The last shot before the credits shows the train pulling away in long shot, uninterrupted by the death inside it. Random events do not stop the system: the train continues its journey and the flow of digital units increases with the morning rush hour. The system is omnipotent - Max's random acts have destroyed a deletion program, but his reactions ultimately only serve to reintegrate himself and Annie into the data flow.

Rybin (p.184) comments on the conclusion's ambivalence, once again drawing attention to the film's digital nature. The finale on the train is digitally composited, with the actors shot on a set 
with greenscreen windows. The passing landscape outside the windows was filmed separately and the two pieces of film then composited into a single image. This image serves as another indication of the manipulable state of people and places within the digital environment, and underscores the idea of the city as a system. Much like the characters in the film are digitised for the purpose of deletion, the environment has been disassembled and reassembled for the purposes of the film. Even while Max's act appears heroic, the film undermines his agency through the very act of representation.

Rybin (p.184) argues that the scene 'suggests an unattainable, permanently dreamy reality ... somehow just beyond the possibilities [of] our circumscribed postindustrial society', a society where lives are programs and, for the most part, run between the data processors of architecture according to their programming. Once the drama is over, the train continues along its programmed route, as Vincent comments on how unimportant his death is: 'a guy gets on the MTA, here in LA, dies. Think anybody'll notice?' Like his victims, he has been deleted, and is accorded the same lack of notice. The overall system is uninterrupted by the removal of this program and the random acts of Max. Just as Double Indemnity and Chinatown ended with gloom and despair, so Collateral ends with the continuation of the LA system, illustrated by the ongoing movement of the cars and train.

Collateral is by no means the only digital noir. Mann's own Miami Vice (2006) features a comparable representation of South Florida and Latin America, while other recent films express similar themes. The Matrix (the Wachowski Brothers, 1999) begins with a noir-esque city that turns out to be a computer generated simulation within the diegesis of the film, the franchise returning to rain-lashed noir streets for the climax of The Matrix Revolutions (2003). In Cypher (Vincenzo Natali, 2002), identities are literally altered, stored and deleted as computer files, the protagonist pursuing such files through landscapes that flit between dimly lit noir and bright open spaces, which may Rybin's 'unattainable, permanently dreamy reality' (p.184). Sin City creates a highly stylised version of the noir cityscape with computer generated backgrounds. A Scanner Darkly (Richard Linklater, 2006) plays on the instability of identity both with the subject of drugs and the 'shiftsuit' worn by the protagonist that constantly alters his appearance, the film's rotoscope animation rendering the images as unstable.

These films demonstrate the reinterpretation of long-standing generic traditions, explored in relation to contemporary concerns. Just as traditional film noir has been critically regarded as reflecting a disillusioned state of mind in America in the 1940s with its sordidness and corruption, so Collateral and its contemporaries reflect the Information Age. Digital noir depicts $21^{\text {st }}$ century affluent American society, and presents lives as digital information, contained by and regarded as computer files. Whereas the hard-boiled noir hero appeared somewhat romantic in his solo quest for justice, in the digital noir romance and justice do not compute. It is a comforting myth that individual decisions can make a difference, a myth we are all too eager to enjoy. Yet we remain dependent on computers, mobile phones, Blackberries, CD-ROMs, memory sticks, and the information superhighway that makes the distribution of this very article possible. The system remains in place and is essential for the continuation of our society. We can celebrate Max's victory and take comfort in the effects of his individual decisions. But we'll still check our e-mail afterwards.

\section{References}

Cawelti, J. G. (2003). 'Chinatown and Generic Transformation.' In: Grant, B. K., ed. Film Genre 
Reader. Austin: University of Texas Press, 243-261

Conard, M. T., ed. (2006). The Philosophy of Film Noir. Lexington: University Press of Kentucky.

Dargis, M. (2004). 'Collateral: Review.' The New York Times, 6th April 2004 [online]. Available from http://query.nytimes.com/gst/fullpage.html?res=9800E4DE123CF935A3575BC0A9629C8B63 (accessed 19th August 2008)

Desser, D. (2003). 'Global Noir: Genre Film in the Age of Transnationalism.' In: Grant, B. K., ed. Film Genre Reader. Austin: University of Texas Press, 516-536.

Falzon, C. (2002). Philosophy Goes To The Movies: an Introduction to Philosophy. London: Routledge.

Graham, J. (2004). 'Collateral Review.' Total Film, Issue 94, October, p. 30.

Grant, B. K., ed (2003). Film Genre Reader. Austin: University of Texas Press.

Gritten, D. (2004). 'Collateral Review.' The Daily Telegraph, 10 ${ }^{\text {th }}$ September 2007 [online]. Available from http://www.telegraph.co.uk/arts/main.jhtml?xml=/arts/2004/09/10/bfmann10.xml [accessed 19th August 2008]

Horsley, L. (2001). The Noir Thriller. Basingstoke: Palgrave

Holt, J. (2006). 'A Darker Shade: Realism in Neo-Noir.' In: Conard, M. T, ed. The Philosophy of Film Noir. Lexington: University Press of Kentucky, 23-40

Krutnik, F. (1991). In A Lonely Street: Film Noir, Genre, and Masculinity. London: Routledge

Olsen, M. (2004). 'It Happened One Night.' Sight \& Sound [online]. Available from www.bfi.org.uk/sightandsound/feature/109/ [accessed 19th August 2008].

Rubin, M. (1999). Thrillers. Cambridge: Cambridge University Press.

Rybin, S. (2007). The Cinema of Michael Mann. Plymouth: Lexington.

Schrader, P. (2003). 'Notes on Film Noir.' In: Grant, B. K., ed. Film Genre Reader. Austin: University of Texas Press, , pp. 229-242.

Silver, A., and Ursini, J., eds (1996). Film Noir Reader. New York: Limelight.

\section{Filmography}

A Scanner Darkly (2006). Directed by Richard Linklater, USA, Warner Independent Pictures.

Amores Perros (2000). Directed by Alejandro González Iñárritu, Mexico, Nu Vision.

Blade Runner (1982). Directed by Ridley Scott, USA, Warner Bros. 
Body Heat (1981). Directed by Lawrence Kasdan, USA, Warner Bros.

Bonnie and Clyde (1967). Directed by Arthur Penn, USA, Warner Bros. / Seven Arts.

Chinatown (1974). Directed by Roman Polanski, USA, Paramount Pictures.

Collateral (2004). Directed by Michael Mann, USA, Dreamworks Pictures/Paramount Pictures.

Cypher (2002). Directed by Vincenzo Natali, USA, Pandora Cinema.

Double Indemnity (1944). Directed by Billy Wilder, USA, Paramount Pictures.

Esprit d'Amour (2000). Directed by William Chang, Hong Kong (distributor unknown).

Gamorrah (2008). Directed by Matteo Garrone, Italy, Optimum Releasing.

In The Line of Fire (1993). Directed by Wolfgang Petersen, USA, Columbia Pictures.

Kiss Me, Deadly (1955). Directed by Robert Aldrich, USA, United Artists.

L.A. Confidential (1997). Directed by Curtis Hanson, USA, Warner Bros.

Manhunter (1986). Directed by Michael Mann, USA, De Laurentiis Entertainment Group.

Memento (2000). Directed by Christopher Nolan, USA: Newmarket Films.

Miami Vice (2006). Directed by Michael Mann, USA, Universal Pictures.

Payback (1999). Directed by Brian Helgeland, USA, Paramount Pictures.

Point Blank (1967). Directed by John Boorman, USA, Metro-Goldwyn-Mayer.

Se7en (1995). Directed by David Fincher, USA, New Line Cinema.

Shark Skin Man and Peach Hip Girl (1998). Directed by Katsuhito Ishii, Japan, Tohokashinsha Film Company.

Sin City (2005). Directed by Robert Rodriguez and Frank Miller, USA, Dimension Films.

Taxi Driver (1976). Directed by Martin Scorsese, USA, Columbia Pictures.

The Big Sleep (1946). Directed by Howard Hawks, USA, Warner Bros.

The Bourne Ultimatum (2007). Directed by Paul Greengrass, USA: Universal Pictures.

The Day of the Jackal (1973). Directed by Fred Zinnemann, Great Britain/France, Warwick Film Productions/Universal Productions France.

The French Connection (1971). Directed by William Friedkin, USA, Twentieth Century Fox. 
The Godfather (1972). Directed by Francis Ford Coppola, USA, Paramount.

The Jackal (1997). Directed by Michael Caton-Jones, USA, Universal Pictures.

The Killers (1946). Directed by Robert Siodmark, USA, Universal Pictures.

The Long Goodbye (1973). Directed by Robert Altman, USA, United Artists.

The Maltese Falcon (1941). Directed by John Huston, USA, Warner Bros.

The Matrix (1999). Directed by Andy and Larry Wachowski, USA, Warner Bros.

The Matrix Revolutions (1999). Directed by Andy and Larry Wachowski, USA, Warner Bros.

The Postman Always Rings Twice (1946). Directed by Tay Garnett, USA, Metro-Goldwyn-Mayer.

The Terminator (1984). Directed by James Cameron, USA, Orion Pictures Corporation.

Touch Of Evil (1958). Directed by Orson Welles, USA, Universal Pictures. 